\title{
Expression of Selected Inflammatory Cytokine Genes in Bladder Biopsies
}

\author{
EDMUND UI-HANG SIM ${ }^{*}$, NUR DIANA ANUAR ${ }^{2}$, TENG-AIK ONG ${ }^{3}$, GUAN- \\ CHOU TEH ${ }^{4}$ \\ ${ }^{1}$ Department of Molecular Biology, Faculty of Resource Science and Technology, University Malaysia \\ Sarawak, 94300 Kota Samarahan, Sarawak, Malaysia; ${ }^{2}$ The John Curtin School of Medical Research, \\ College of Medicine, Biology and Environment, The Australian National University, Canberra, ACT, \\ Australia; ${ }^{3}$ Department of Surgery, Centre for Medicine, University of Malaya, 50603 Kuala Lumpur, \\ Malaysia; ${ }^{4}$ Department of Urology, Sarawak General Hospital, 93586 Kuching, Sarawak, Malaysia
}

\begin{abstract}
Besides the deregulation of oncogene and tumour suppressor gene, bladder carcinoma can also be caused by inflammation. To date, the association of inflammatory cytokines with carcinoma of the bladder (especially the transitional cell carcinomas) is not fully understood. In this study, we report an attempt to examine expression patterns of pro- and anti- inflammatory cytokine genes from normal and tumour tissue biopsies of the human bladder. Our molecular assays involved the use of the GeneXPTM Human Cyto-3 kit and the Reverse Transcription - Polymerase Chain Reaction test. Due to limitation in our experimental process, mainly attributed by inconsistencies in the results obtained between the two assay systems, we cannot reach a conclusion regarding the association of the six selected inflammatory cytokine genes $(I L-8, I L-12 A, I L-18, T G F-\beta 1$, TGF$\beta 2$, and $T G F-\beta 3$ ) with bladder carcinoma. However, our data provided early novel evidence of expression of four inflammatory cytokine genes, namely $I L-12 A, T G F-\beta 1$, TGF- $\beta 2$, and $T G F-\beta 3$ in tissues derived from the human bladder.
\end{abstract}

Keywords: Expression analysis, inflammatory cytokines, bladder biopsies

\section{INTRODUCTION}

Studies have shown that over-proliferation of cells due to deregulation of oncogenes and tumour suppressor genes, and certain epigenetic mechanism are not the only causative factors of cancer (Coussens \& Werb, 2001). In fact, inflammation and infections has been suggested to be amongst the triggers of tumour initiation (Lin \& Karin, 2007). Inflammation-mediated carcinogenesis can be explained, in part, by the activation of the inflammatory cells that release mutagenic oxidant-generating enzyme (Michaud, 2007), which may cause irreversible genomic alterations in proliferating epithelial cells (Coussens \& Werb, 2007).

According to Michaud (2007), the association between inflammation and carcinogenesis in squamous cell carcinoma of the bladder accounts for the high occurrence of this subtype of bladder cancer in many developing countries where parasitic infection

*Corresponding author:uhsim@frst.unimas.my by Schistosoma haematobium is common. However, evidence of such association in cases of transitional cell carcinoma (TCC) of the bladder, a predominant subtype in most developed country and also in Malaysia, is less clear. In this short report, we reveal an attempt to investigate inflammation as a potential contributing event in local cases of transitional cell carcinoma of the bladder. We sought the strategy of simultaneous expression analysis of selected pro- and anti- inflammatory cytokine genes in normal and tumour bladder biopsies. Our hypothesis was that differential expression of inflammatory cytokine genes between normal and tumour biopsies, and also between pro- and anti-inflammatory cytokines would form the basis to suspect a link between inflammation and carcinogenesis of TCC.

\section{MATERIALS \& METHODS}

\section{Sample collection and total RNA isolation}

Normal bladder and tumour tissue biopsies were from patients admitted to the Sarawak 
General Hospital (Kuching, Sarawak) who have provided informed consent. Collected tissues were stored in cryovials and snap frozen in liquid nitrogen immediately after excision. They were subsequently stored at $-80^{\circ} \mathrm{C}$ freezer in the laboratory until use. Twenty one tumours and four normal tissues were used. Ten to twenty miligrams $\left(0.5 \mathrm{~cm}^{2}\right)$ of tissue specimen were used in the isolation process. The total RNA isolation was conducted in an RNase-free environment. TRIzol Tri Reagent was used to lyse the tissues and extract the RNA and these were carried out according to the manufacturer's protocol (Invitrogen, USA). The RNA pellet was dissolved in 30 to $50 \mu 1$ of nuclease-free water (Promega, USA) depending on the size of the pellet. After DNase treatment, the total RNA extracted was quantified using UV spectrophotometer (Ultrospec 1100) at $\mathrm{A}_{260}$ and $\mathrm{A}_{280}$ wavelength.

\section{Gene XP ${ }^{\mathrm{TM}}$ Human Cytokine Assay and RT- PCR}

A total of $1 \mu \mathrm{g}$ of total RNA was used in reverse transcription reaction. An M-MLV reverse transcriptase (Promega, USA) was used in this reaction to a final volume of $20 \mu \mathrm{l}$, and this was done according to the manufacturer's protocol. For the Gene $\mathrm{XP}^{\mathrm{TM}}$ Human Cytokine Assay kit, six genes were designed to be amplified simultaneously. The target amplicons consist of $I L-8$ ( $\sim 590 \mathrm{bp}), T G F-\beta 3$ ( $\sim 470 \mathrm{bp})$, $I L-12 A$ ( $\sim 360 \mathrm{bp}), T G F-\beta 1$ ( $290 \mathrm{bp}), T G F-\beta 2$ ( $\sim 240 \mathrm{bp})$ and $I L-18$ ( 160 bp). Briefly, the PCR was carried out by mixing $10 \mu \mathrm{l}$ of $2 \mathrm{X}$ master mix PCR, $4 \mu \mathrm{l}$ of $5 \mathrm{X}$ human cyto-3 primer, $200 \mathrm{ng}$ of cDNA and sterile $\mathrm{dH}_{2} \mathrm{O}$ to a final volume of $20 \mu \mathrm{l}$. The kit was also supplemented with positive control DNA. Six microlitres of the DNA was used in the PCR reaction as positive control to the PCR reaction. The mixture was the subjected to PCR amplification at $94^{\circ} \mathrm{C}$ for 15 mins, 40 cycle of $94^{\circ} \mathrm{C}$ for $30 \mathrm{~s}, 63^{\circ} \mathrm{C}$ for $90 \mathrm{~s}, 72^{\circ} \mathrm{C}$ for $90 \mathrm{~s}$ and final extension at $72^{\circ} \mathrm{C}$ for 10 mins. Ten microlitres of PCR products was resolved in $2 \%$ agarose gel pre-stained with EtBr.

Results obtained from the Gene $\mathrm{XP}^{\mathrm{TM}}$ Human Cytokine Assay kit were tested using
RT-PCR, and was done in triplicate for each gene. For all RT-PCR analysis, the cDNA content used was standardized to $200 \mathrm{ng}$. Briefly, $12.5 \mu \mathrm{l}$ of ultrapure water, $5.0 \mu \mathrm{l}$ of $5 \mathrm{X}$ Green buffer, $2.5 \mu 1$ of $25 \mathrm{mM} \mathrm{MgCl}_{2}, 0.5 \mu 1$ of $10 \mathrm{mM}$ dNTP, $1.0 \mu \mathrm{l}$ of $25 \mathrm{pmole} / \mu \mathrm{l}$ of forward primer, $1.0 \mu \mathrm{l}$ of $25 \mathrm{pmole} / \mu \mathrm{l}$ reverse primer and $200 \mathrm{ng}$ of cDNA (template) were mixed to a final reaction volume of $25 \mu \mathrm{l}$ in a $0.2 \mathrm{ml}$ tube. PCR was performed using PTC-2000 Peltier Thermal Cycler (MJ research, USA). Briefly, the reaction was subjected to initial denaturation at $95^{\circ} \mathrm{C}$ for 5 mins, 35 cycles of denaturation at $95^{\circ} \mathrm{C}$ for $1 \mathrm{~min}$, annealing at 60 $61^{\circ} \mathrm{C}$ for $1 \mathrm{~min}$ and extension at $72^{\circ} \mathrm{C}$ for 2 mins. The primers designed in RT-PCR confirmation test were mRNA specific (exonexon boundaries). Table 1 indicates the list of primers and the optimized annealing temperature. Ten microlitres of amplified product were resolved in $2 \%$ agarose gel. The intensity of the bands was quantified using AlphaEase ${ }^{\circledR} \mathrm{FC}$ Imaging Software (Alpha Innotech Corporation, California, USA). In this study, the quantification was done by using 50 bp DNA marker as a reference marker. The $G A P D H$ gene was used as an internal control to affirm the equimolar concentration of our cDNA. The intensity value of each band was normalized against that of $G A P D H$, and the final value considered as normalised value.

\section{RESULTS}

\section{Cytokine profiling by Gene $\mathrm{XP}^{\mathrm{TM}}$ Human Cytokine Assay}

As shown in Figure 1, amplification using the cytokine kit yielded six bands as stated in the manufacturer's protocol. The amplified targets consist of $I L-8$ ( $\sim 590 \mathrm{bp}), T G F-\beta 3$ ( $\sim 470 \mathrm{bp})$, $I L-12 A$ ( $\sim 360 \mathrm{bp}), T G F-\beta 1$ ( $\sim 290 \mathrm{bp}), T G F-\beta 2$ ( $\sim 240 \mathrm{bp})$ and $I L-18(\sim 160 \mathrm{bp})$. Positive control DNA provided in the kit was used. However, no bands for $I L-8$ and $I L-12 A$ were visible. Only one of our tumour samples (S6T) shows the presence of all six bands of the targeted transcripts. The TGF- $\beta 3$ amplicon was not detected in Samples S12T and S26T, while $I L$ $12 A$ is absent in Samples S7T, S21T and S26T. 
Table 1. List of primers used in RT-PCR confirmation test.

\begin{tabular}{|c|c|c|c|c|}
\hline Primer & $\begin{array}{c}\text { Primer Sequence } \\
\left(5^{\prime}-3^{\prime}\right)\end{array}$ & $\begin{array}{l}\text { Primer } \\
\text { Length } \\
\text { (bases) }\end{array}$ & $\begin{array}{c}\text { Optimized } \\
\text { Annealing } \\
\text { Temperature }\left({ }^{\circ} \mathrm{C}\right) \\
\end{array}$ & $\begin{array}{c}\text { Expected size } \\
\text { of amplicons } \\
\text { (bp) } \\
\end{array}$ \\
\hline \multicolumn{5}{|l|}{$T G F-\beta 1$} \\
\hline $\begin{array}{c}\text { Fwd } \\
T G F-\beta 1\end{array}$ & gga cta tcc acc tgc aag act atc & 24 & 60 & 448 \\
\hline Rev & gaa ttg ttg ctg tat ttc tgg tac a & 25 & & \\
\hline$T G F-\beta 2$ & & & & \\
\hline $\begin{array}{c}\text { Fwd } \\
T G F-\beta 2\end{array}$ & aaa atg cac tac tgt gtg ctg ag & 23 & 60 & 515 \\
\hline $\begin{array}{c}\text { Rev } \\
T G F-\beta 3\end{array}$ & atc tga tat agc tca atc ct & 2 & & \\
\hline $\begin{array}{c}\text { Fwd } \\
T G F-\beta 3\end{array}$ & ctc ttc cca get cac aca tga a & 22 & 60 & 397 \\
\hline $\begin{array}{l}\text { Rev } \\
\text { IL-8 }\end{array}$ & ctt tag ggc aga cag cca gtt & 21 & & \\
\hline Fwd & ctc act gtg tgt aaa cat gac ttc c & 25 & 61 & 321 \\
\hline $\begin{array}{l}I L-8 \\
\text { Rev }\end{array}$ & ttt tat gaa ttc tca gec ctc ttc & 24 & & \\
\hline$I L-18$ & & & & \\
\hline $\begin{array}{l}\text { Fwd } \\
I L-18\end{array}$ & aac cta ttt gtc gca gga ata aag a & 2 & 61 & 608 \\
\hline $\begin{array}{c}\text { Rev } \\
I L-12 A\end{array}$ & ata gct agt ctt cgt ttt gaa cag $t$ & 25 & & \\
\hline $\begin{array}{c}\text { Fwd } \\
I L-12 A\end{array}$ & ttc ca gaga gac ctc ttt cat aac taa $t$ & 28 & 61 & 466 \\
\hline Rev & tca gat agc tca tca ctc tat caa tag tc & 29 & & \\
\hline
\end{tabular}

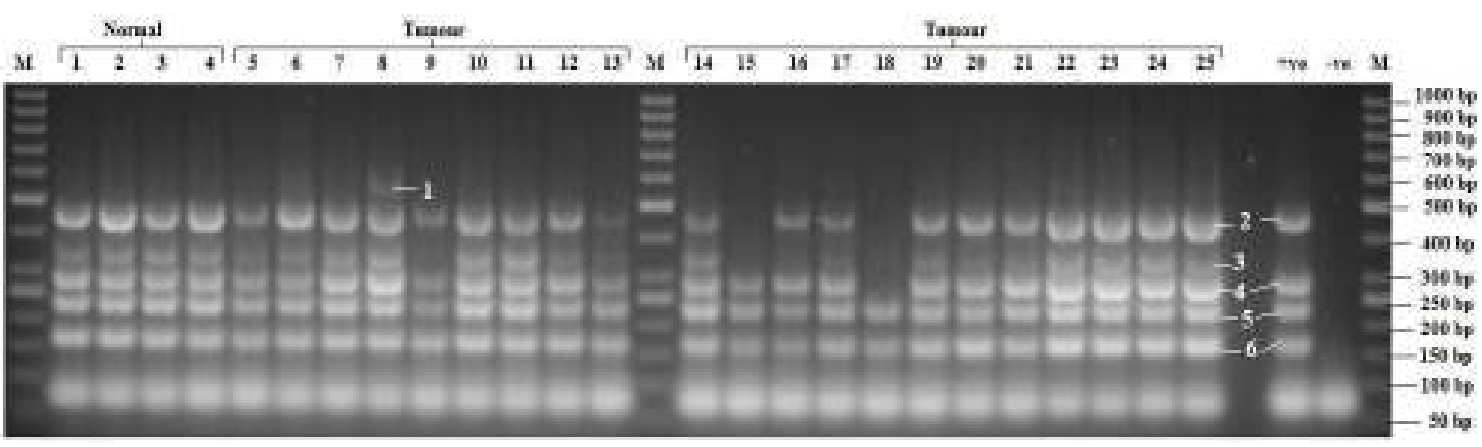

Figure 1. The amplification of selected cytokines via GeneXPтм Human Cyto-3 assay kit. M represents 50 bp DNA marker. Band 1 represents $I L-8$ gene, Band 2: TGF- $\beta 3$; Band 3: $I L-12 A$; Band 4: TGF- $\beta 1$; Band 5: TGF$\beta 2$ and Band 6: $I L-18$. Lane M represents 50 bp DNA marker, Lane 1: S10N, Lane 2: S14N, Lane 3: S27N, Lane 4: S29N, Lane 5: S2T, Lane 6: S3T, Lane 7: S4T, Lane 8: S6T, Lane 9: S7T, Lane 10: S9T, Lane 11: S12T, Lane 12: S16T, Lane 13: S19T, Lane 14: S20T, Lane 15: S21T, Lane 16: S24T, Lane 17: S25T, Lane 18: S26T, Lane 19: S27T, Lane 20: S28T, Lane 21: S29T, Lane 22: S30T, Lane 23: S31T, Lane 24: S33T and Lane 25: S34T. 


\section{RT-PCR confirmation test}

Figure 2 shows the amplification of $T G F-\beta 1$, $T G F-\beta 2, \quad T G F-\beta 3, I L-8, I L-18$, and $I L-12 A$ respectively. In RT-PCR confirmation test, the mean of the band intensity from the triplicates was used to plot a graph that summarizes the expression level of all six genes throughout the sample. Figure 3 shows the expression level of the six genes generated from Gene XP Human Cyto-3 kit and that of the same genes from RTPCR test. The amplification of TGF- $\beta 1$ at $\sim 450$ bp was detected in all samples except in two of the normal tissues (S10N and $\mathrm{S} 27 \mathrm{~N}$ ) (Lane 1 and 3, Figure 2) and two of the tumour tissues (S2T and S21T) (Lane 5 and 15, Figure 2). These results did not tally with the cytokine assay kit (Figure 1) which shows the presence of TGF- $\beta 1$ in all tissues. For TGF- $\beta 2 \quad(\sim 500$ $\mathrm{bp})$, the amplicon was detected in minute amount in all samples except in four tumour samples S30T, S31T, S33T and S34T (Lane 22-25, Figure 2). These results also did not tally with the cytokine assay kit which shows the presence of this amplicon in all samples (Figure 1). For $T G F-\beta 3$, the amplicon is observed in two of the normal tissues (S27N and S29N, Lane 3 and 4) and five of the tumour tissues (S3T, S30T, S31T, S33T and S34T) (Lane 6, 22-25, Figure 2). Again, this is not in agreement with the cytokine assay kit in which this amplicon is absent in two tumour sample, S21T and S26T (Figure 1). IL-8 is consistently detected in all samples except in S7T (Lane 9, Figure 2). This result contradicts the expression profile generated from the cytokine assay kit which shows the presence of $I L-8$ in only S6T (Figure 1). $I L-18$ is observed in all samples except in S10N, S14N and S27N. Its presence in the second and third replicate was detected in a minute amount. Its presence in cytokine assay kit however was easily detected throughout the samples studied. Finally, in the case of $I L-12 A$, of which is faintly observed samples S27T and S28T, but clearly observed in S16T, S30T, S31T, S33T and S34T (Figure 2). However, it is detected in all samples except for S7T and
S21T in the results from the Gene XP Human Cyto-3 kit (Figure 1).

\section{DISCUSSION}

Results from the two assays done did not provide conclusive evidence to support the role(s) of pro-inflammatory cytokine genes ( $I L$ $8, I L-12 A$ and $I L-18)$ and anti-inflammatory genes $(T G F-\beta 1, T G F-\beta 2$ and $T G F-\beta 3)$ in the tumourigenesis of BC. Firstly, results from the RT-PCR assays on all six cytokine genes tested are not consistent with observation of their expression profiles procured via the Gene XP Human Cyto-3 kit assay. Secondly, there is no definitive pattern of expression among any of the six genes that showed differential level between normal and tumour samples. Lastly, unless a quantitative assessment of expression level is investigated (via real time PCR strategy), any consideration on observed expression patterns or differential expression (if any) remains an approximation, at best. Indeed, a repetition of similar experiments is required in order that proper conclusion can be inferred. This is especially so when the test on the positive control for the Gene XP Human Cyto3 kit also requires redoing.

Except for $I L-8$ and $I L-18$, the cytokine genes selected for this study have never been brought into the context of gene expression activities in bladder-derived tissues. Despite inconclusive findings, we did show evidence of expression of $I L-12 A, T G F-\beta 1$, TGF- $\beta 2$, and $T G F-\beta 3$ in bladder tissues. In the case of $I L-8$, Inoue and coworkers (2000) have shown it to be involved in angiogenesis of bladder tumour in nude mice. In addition, Thalmann and coworkers (2000) revealed that the level of $I L-8$ and $I L-18$ can be used to monitor the response of superficial bladder cancer to Bacillus Calmette-Guerin (BCG)-based intravesical therapy. Inevitably, more work has to be done, and our experiments has to be repeated in order that rational inferences can be obtained regarding the role(s) of $I L-12 A, T G F-\beta 1$, TGF$\beta 2$, and $T G F-\beta 3$ in bladder carcinoma. 

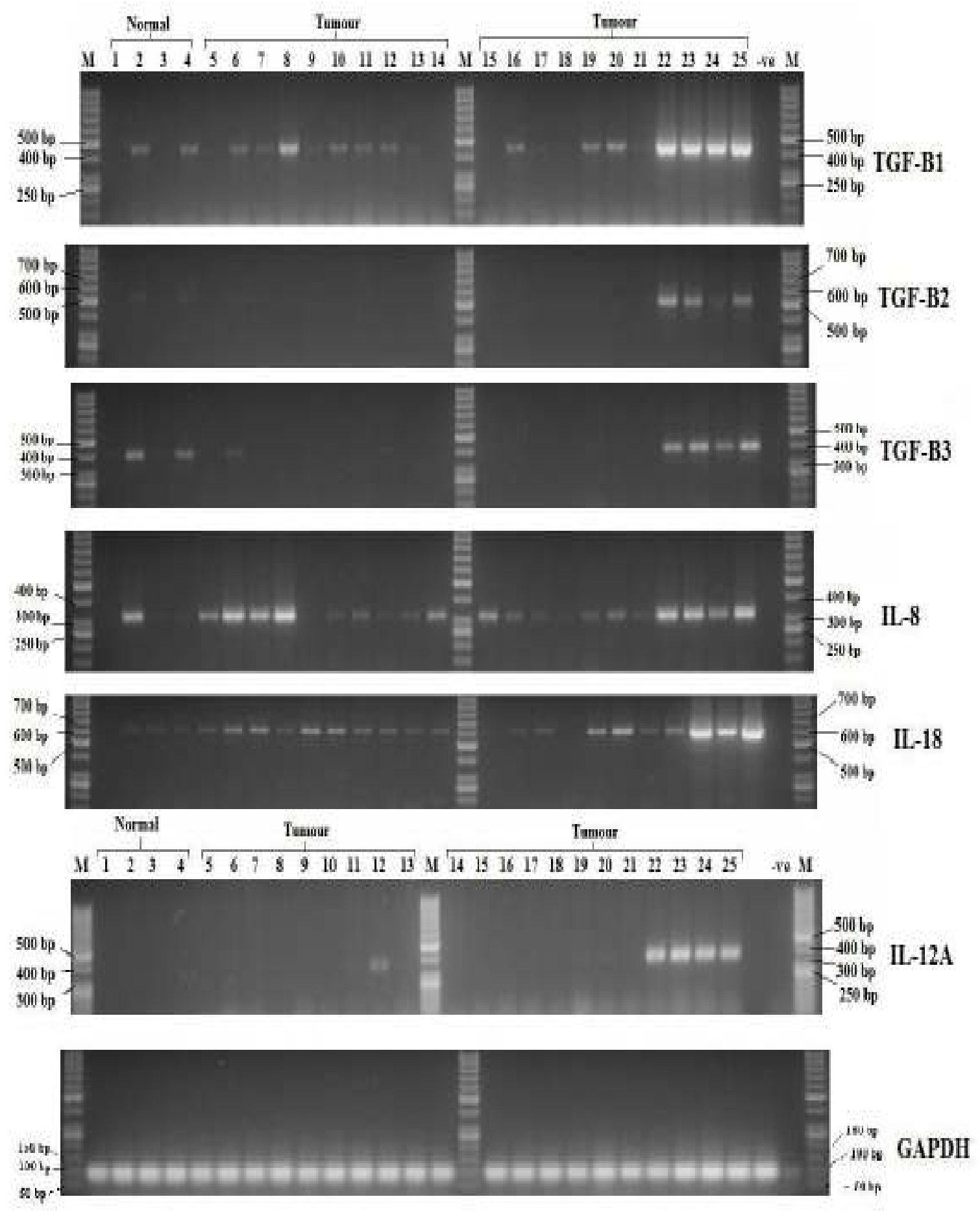

Figure 2. RT-PCR validation on genes from GeneXP assay. The item for each lane is as indicated in Figure 1. 

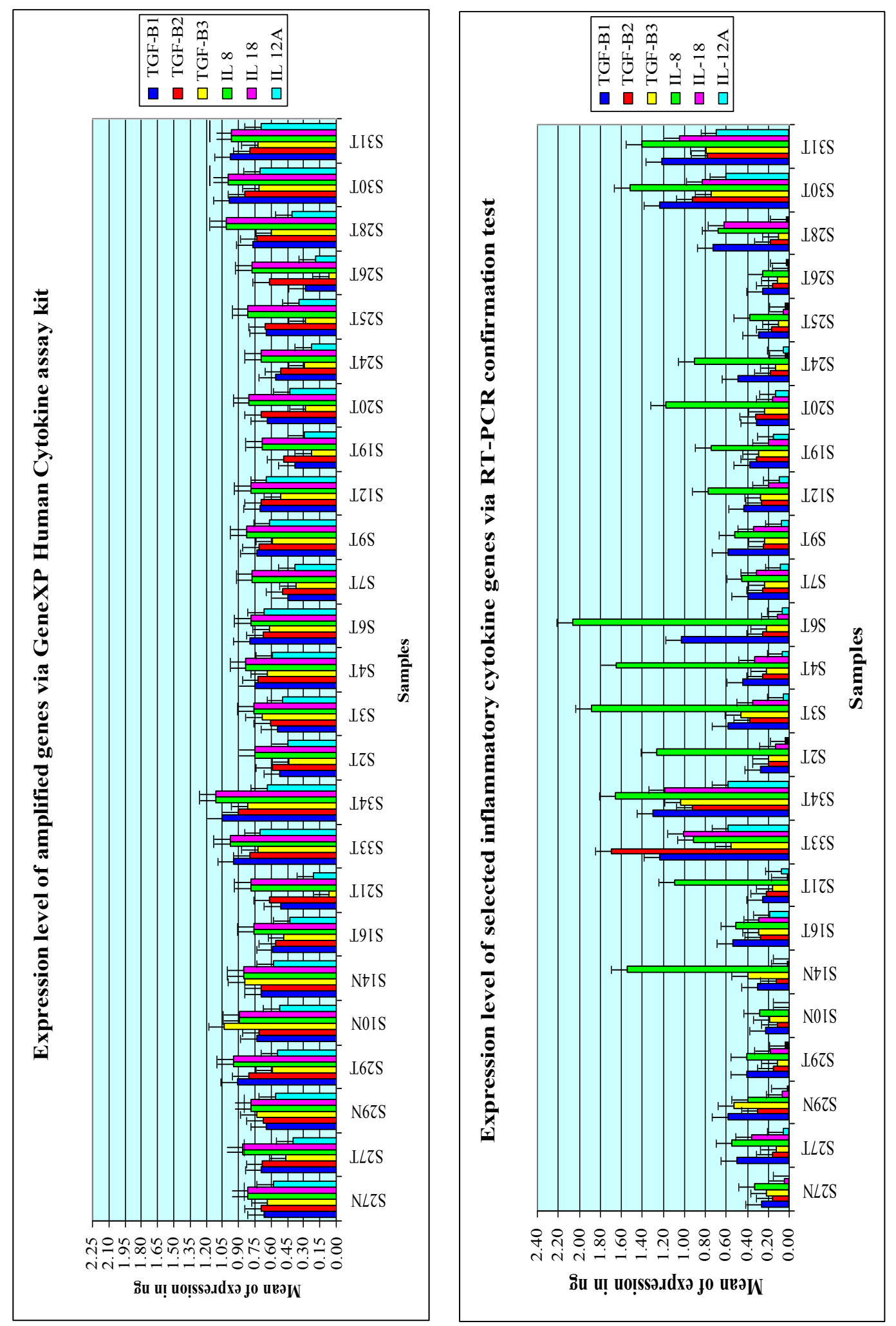

Figure 3. Charts of the expression levels of the amplified genes via GeneXPTM Human Cytokine assay kit and selected inflammatory cytokine genes as tested via RT-PCR. This graph was plotted based on the means of the normalised value. 


\section{REFERENCES}

Coussens, L.M. \& Werb, Z. (2001). Inflammatory cells and cancer: Think Different! Journal of Experimental Medicine, 193(6): F23-F26.

Inoue, K., Slaton, J.W., Kim, S.J., Perrotte, P., Eve, B.Y., Bar-Eli, M., Radinsky, R., \& Dinney, C.P.N. (2000). Interleukin 8 expression regulates tumorigenicity and metastasis in human bladder cancer. Cancer Research, 60: 2290-2299.

Lin, W.W. \& Karin, M. (2007). A cytokinemediated link between innate immunity, inflammation and cancer. The Journal of Clinical Investigation, 117(5): 1175-1183.
Michaud, D.S. (2007). Chronic inflammation and bladder cancer. Urologic Oncology: Seminars and Original Investigations, 25: 260-268.

Thalmann, G.N., Sermier, A., Rentsch, C., Mohrle, K., Cecchini, M.G., \& Studer, U.E. (2000). Urinary interleukin-8 and 18 predict the response of superficial bladder cancer to intravesical therapy with Bacillus CalmetteGuerin. The Journal of Urology, 164: 21292133. 